\title{
Asymmetric $\gamma$-Borylation of Aliphatic Amides and Esters
}

\section{Key words}

$\mathrm{C}\left(\mathrm{sp}^{3}\right)-\mathrm{H}$ activation

borylation

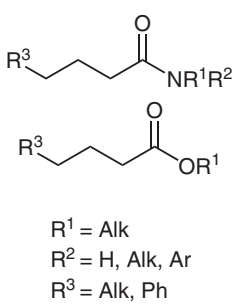

(BPin) 2 (1 equiv) $\left[\mathrm{Ir}^{*} \mathrm{OMe}(\mathrm{cod})\right]_{2}(1.5 \mathrm{~mol} \%)$

$(R, R)-\mathrm{L}(3 \mathrm{~mol} \%)$ receptor ligand (3.3 mol\%) 2,6-Iutidine ( 0.75 equiv)

PhMe-CPME (1:1), $25^{\circ} \mathrm{C}, 48 \mathrm{~h}$

$\mathrm{R}^{2}=\mathrm{H}$, Alk, $\mathrm{A}$

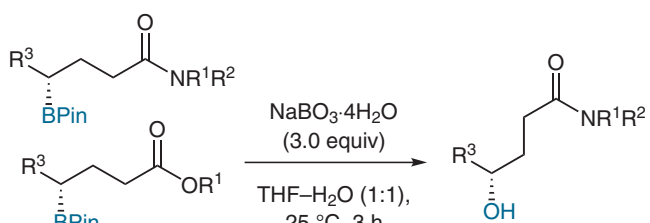

asymmetric catalysis

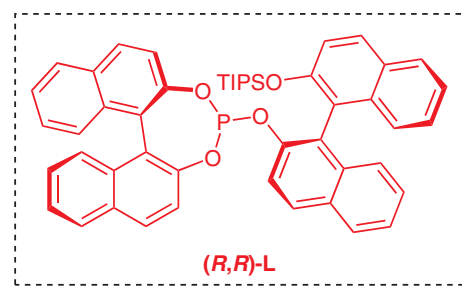

$$
\begin{aligned}
& 25^{\circ} \mathrm{C}, 3 \mathrm{~h} \\
& 30 \text { examples }
\end{aligned}
$$

$61-99 \%$ isolated yield

$90-99 \%$ ee

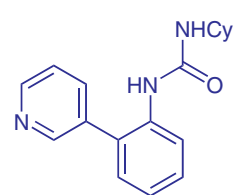

Selected examples:<smiles>CCCCCC(CC)CCC(=O)NCCCC</smiles><smiles>CC[C@@H]([O+])CCC(=O)Nc1ccccc1</smiles><smiles>CC[C@H](O)CCC(=O)N1CCOCC1</smiles><smiles>CCCCCC([NH3+])=O</smiles>

$89 \%$ yield, $93 \%$ ee $91 \%$ yield ( $83 \%$ at gram scale), $98 \%$ ee

$73 \%$ yield, $92 \%$ ee

$99 \%$ yield, $>99 \%$ ee<smiles>CCOC(=O)CCC([B]c1ccccc1)CC</smiles><smiles>CCC([B]c1ccccc1)CCC(=O)OCc1ccccc1</smiles><smiles>CC/C=C\C[C@H](Br)CCC(=O)Nc1ccccc1</smiles><smiles>O=C(CC[C@@H](O)c1ccccc1)NC(=O)c1ccccc1</smiles>

$80 \%$ yield, $90 \%$ ee $83 \%$ yield, $95 \%$ ee $81 \%$ yield, $94 \%$ ee $81 \%$ yield, $96 \%$ ee<smiles>CCC(CCC(=O)Nc1ccccc1)c1cccc(OC)c1</smiles>

$64 \%$ yield, $97 \%$ ee

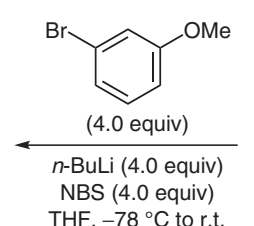

THF, $-78{ }^{\circ} \mathrm{C}$ to $r$.t.

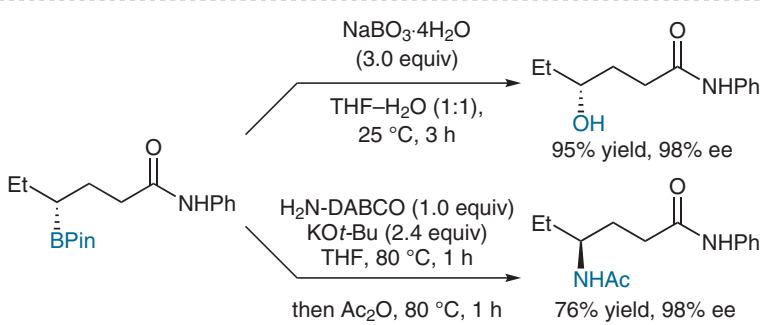

Significance: The authors report on an asymmetric borylation of aliphatic amides and esters in $\gamma$ position. The efficient catalytic system delivers chiral pinacolboronates in high yield and enantiomeric excess.
Comment: The complex catalytic system is comprised of an iridium precatalyst, a chiral ligand and a receptor ligand. The receptor ligand has a pyridine moiety intended for binding to the catalyst and a urea moiety for substrate binding. The absence of either of these components results in no reaction. 2,6-Lutidine has a positive impact on both yield and enantiomeric excess. Preliminary quantum chemical calculations show that the amide substrate is bound to the catalytic cavity not only through hydrogen bonding with receptor ligand but also through other noncovalent interactions. 